\title{
Cambodian Child Migrant Workers in the Rong Kluea Market Area in Thailand
}

\author{
Utit Sankharat $^{1}$ \\ ${ }^{1}$ Research Center for Asia Pacific Development Studies, Faculty of Liberal Arts, Prince of Songkla University, \\ Hat Yai, Thailand \\ Correspondence: Utit Sankharat, Research Center for Asia Pacific Development Studies, Faculty of Liberal Arts, \\ Prince of Songkla University, Hat Yai, Songkhla 90112, Thailand. E-mail: Utit.s@psu.ac.th
}

$\begin{array}{lr}\text { Received: April 10, } 2013 & \text { Accepted: June 24, } 2013 \quad \text { Online Published: August 30, } 2013 \\ \text { doi:10.5539/ass.v9n11p24 } & \text { URL: http://dx.doi.org/10.5539/ass.v9n11p24 }\end{array}$

\begin{abstract}
The problem of foreign child workers migration to Thailand day will expand at present especially the Thai border with neighboring countries. The child workers force these were right. Child workers is the need of the employer. Migrant children and many victims of human trafficking. The whole country's social origin and destination. The area along the Thai many points became the area of migrant children. Lead to the question that causes any is driven. Or support workers to these children across the border into the labor market in the country.

The objectives of this study were to investigate: 1) factors influencing Cambodian child migrant workers in the Rong Kluea Market area in Aranyaprathet District, Sa Kaeo Province; 2) occupations of Cambodian child migrant workers in the Rong Kluea Market area. The data of this qualitative research were collected through interviewing and observing life of 24 Cambodian child migrant workers in the Rong Kluea Market area. The field data were classified into categories, interpreted, decoded, synthesized and tested using triangulation.

The results of the study revealed that there were three factors that made the Cambodian child workers in the Rong Kluea Market area migrate: 1) internal factors from the country of origin which were poverty and economic status of their family, family conditions, household debts, and a lack of education; 2) migration of the foreign child workers was migration from their place of origin in rural areas of Cambodia to new areas in Poipet, Ou Chrov District, Banteay Meanchey Province, and crossing the border to be workers in the Rong Kluea Market area in Thailand; and 3) factors in Thailand which was the Rong Kluea Market area, the trade area on the Thailand-Cambodia border that was a special economic source, employment source, and hope for higher income than the country of origin.

The occupations of Cambodian child migrant workers in the Rong Kluea Market area were found to consist of 10 main categories: 1) holding umbrellas to provide shade for tourists, 2) collecting garbage items for sale, 3) taking people across the border through a shortcut, 4) cleaning frogs, 5) cutting off grasshoppers' wings, 6) scraping fish flesh and scaling fishes, 7) pushing goods carts, 8) peddling goods and fruit, 9) shop as workers sistants, and 10) selling sex services. Child workers can choose freely the kind of work they want to do either do it on their own or to be employed and directly depend on an employer. Child workers, some victims of human trafficking. Employment and some illegal workers. The exploitation and exploit workers unfairly. Cambodian child migrant workers these became the new issue problem of the border area.
\end{abstract}

Keywords: Cambodian child workers, migration, Rong Kluea market

\section{Introduction}

The end of the superpowers after the Cold War (1945-1991) during which the free world and the communist world tried to fight each other using many different methods except openly fighting a war in order to obstruct power expansion of each other resulted in openings of borders in many countries worldwide. The détente of power control from the superpowers that used to limit the moves of people, goods, capital and thoughts have resulted in more migration (Donnan \& Wilson, 1996) and flows of people from one country to another, especially countries with good economy were destinations attractive to people of other countries who migrated for work over the border. Consequently, illegal migration and illegal actions along the borders have been among important problems at present. 
Migration for work in other countries has been worldwide phenomena as a result of globalization, capital moves, trade exchanges, and production of goods and service exchanges. This has also resulted in cross-national employment. Presently, the size of cross-national employment includes 86 million workers or three percent of the entire workforce of the world. Most of them move to work or to seek for work in more developed countries. Approximately, 3.3 million people migrate for long-term employments or to settle in the country of destination (International Organization for Migration, 2008). Worldwide, the International Labor Organization estimated that irregular migration accounts for $10-15 \%$ of the entire number of migration and immigrants (International Labor Organization, 2004 cited in International Organization for Migration, 2008).

Thailand is one of the countries with illegal migration of foreign workers including a high rate of trafficking in women and children because it is a country of origin, destination, and transit for migrant workers and human trafficking. The trends in labor force flows from its neighboring countries, especially Laos, Cambodia, Myanmar, Vietnam, and China to Thailand have increased every year. This is because Thailand in one of the Southeast Asian countries with a high rate of employment. Organizations and agencies related to cross-national workers have estimated that a large number of cross-national workers have not been registered in the governmental system, and approximately the number might be as high as three million across the country (Sciortino \& Punpuing, 2009) including some child workers.

Child workers enter Thailand in many different ways depending on each area, and for different types of work. In the border areas, some child workers cross the border back and forth daily while others cross the border to work seasonally. They usually work at the same place as they used to do. In some areas, groups of migrant workers move in for long-term work and living with help from their friends or relatives or people that they know. Most children enter Thailand with their parents, siblings or relatives.

Foreign child workers are easily exploited because they are afraid they might get a consequence of their illegal migration. They dare not escape and cannot communicate in Thai. In addition, they have to tolerate because the conditions in Thailand are better than those in the country of origin. The attitudes of most people towards foreign child workers is that these children causes social problems and should not be helped because there are still a large number of Thai children who are in problematic situations and need help, too. As a result, foreign children are neglected and are concealed in different parts of society. Foundation for Child Development that helps child labor force found that more foreign child workers are exploited than their Thai counterparts in terms of wage that is too low; they are cheated of their wages; they are confined to the workplace, beaten, and badly treated. Some female child workers are raped by their employers or brokers. Help and sending them back to the country of origin are not the answers to the problem because many children come back repeatedly. For many of them, "sending back" is sending them to face even a worse situation because in the country of origin there are many dangerous fronts from the brokers as well as oppression in the country.

There are a lot of Cambodian nationality child workers who work in the Rong Kluea Market area where there are a lot of brand new goods and second hand goods, large and small businesses such as a casino on the other side of the border in Poipet that attracts a lot of Thai and other tourists who like gambling. The development in the border area has caused a flow of Cambodian labor force, and many people from remote areas in the border towns of Poipet and Aranyaprathet have moved for work in the trade area. Even though Thailand and Cambodia had conflicts related to the Temple of Khao Phra Viharn, in particular, the borderline during 2010-2011, border trading in the Rong Kluea Market area went on regularly as usual. Cambodians still crossed the border back and forth to work regularly though the conflict had caused the border to be closed for a period of time; however, the number of foreign child workers did not decreased.

The migration and border-crossing of Cambodian child workers to work in the Rong Kluea Market area is interesting, especially, in terms of their way of life, factors attracting them to the market area, the types of work they do, and the characteristics of their work. These are the issues that the researcher saw the need for understanding, particularly of the existing situation of migrant Cambodian child workers in the Rong Kluea Market area in Thailand so that the data obtained can be used by related organizations in managing the situation and solving the problem.

\section{Objectives}

1) To investigate factors influencing migration of Cambodian child workers to work in the Rong Kluea Market area in Thailand, and

2) To explore occupations of Cambodian child workers in the Rong Kluea Market area. 


\section{Literature Review}

Sasanasuphin, Ayuwat, and Tongyu, (2011) whose study on Transnational Migration Processes of Victims-Migrant Trafficking aimed to explore migration processes of victims of human trafficking in Thailand, and found that migrants who were victims of human trafficking were children and youth who did not have any experience in transnational migration and had low income. They were persuaded by human traffickers to move out of their country of origin. They expected to have high wages and save some money to take back. They had wrong knowledge or understanding about the country of destination, and thus, were cheated by human traffickers to move out of their place of origin. Moreover, they did not know much about traveling, and therefore, had to depend on the human traffickers for traveling.

In their study on Hierarchical Citizenship in a World of Unequal Nation-States, Castles \& Miller (1993) explain that factors influencing people to make a decision to migrate from their birthplace were not only economic push and pull factors, but also many other economic, political, social, cultural, and legal factors that are all related throughout the transnational migration. These factors are not different but rather connected to each other and become push factors.

Pearson, Punpuing, Jampaklay, Kittisuksathit, \& Prohmmo (2006) in their study on "The Mekong Challenge: Underpaid, Overworked and Overlooked: The Realities of Young Migrant Workers in Thailand" reflects the life of stateless migrants in the issues related to their work, living conditions, children's education, rights and protection as transnational workers who are diversified in their occupations.

A study by Lee (2005) on Human Rights and Gender: Irregular Migrant Workers from Burma in Thailand shows that when referring to stateless people, especially cross-border migrant workers from Burma in Thailand in what makes them stateless, there are more factors to consider than merely taking nationality as the only factor making them stateless. There are other related factors that make cross-border migrant workers from Burma stateless and are not protected according to human rights principles.

Castles (2005) states in his study on Hierarchical Citizenship in a World of Unequal Nation-States that the cross-border migration process that makes people stateless, and the process when citizens of one state cross over to another state where they are included in or excluded from the same governing unit are considered a universalistic and inclusive process, on the one hand. On the other hand, such process leads to culturally specific and exclusive creation. Being excluded from the state-nation because of their culture is different from the "national culture" can eventually lead people to being "stateless" persons.

The border-crossing of Cambodian children to work in the Rong Kluea Market area is a border-crossing process that is illegal. Most of them enter the country illegally and most are uneducated, poor, and some have no nationality. These are stateless children who live near the border and cross back and forth to work in the Rong Kluea Market area. Thus, they are illegal and underpaid workers who would do any kind of work available.

\section{Research Method}

The study on life of Cambodian child workers in the Rong Kluea Market area in Thailand is a qualitative study conducted with the following research methodology.

\subsection{Key Informants}

Key informants for this study were 24 Cambodian child workers holding different jobs in the Rong Kluea Market area, and secondary informants were people who could give information about the way of life of the foreign child workers. These groups of people consisted of three people who were vendors in Rong Kluea Market who were and were not employers of these children, and another person who could give information about the foreign child workers' way of life in Thailand and Cambodia.

\subsection{Study Area}

The area where the data were collected were selected from the Rong Kluea Market area consisting of six small-size markets: 1) Talad Lang (Municipal market), 2) Talad Benchawan, 3) Talad Rungsap (Fish market), 4) Taland Rattanatham (Insect market), 5) Talad Det Thai (second-hand shoe market), and 6) Talad Sapsomboon. All of these markets are in the Special Economic Zone (SEZ), an important place in the eastern part of the country that is the area of origin, destination, and transit that Cambodian child workers can travel to in order to go on to their destination where they wish to work. In this study, the researcher himself had limitation in understanding the Cambodian language, and therefore, needed to hire two Cambodian interpreters, one Cambodian nationality and the other Thai nationality to communicate with the foreign child workers. 


\subsection{Data Collection}

1) The data were collected from related documents, research reports, books, and journals from online sources and educational institutions and related organizations.

2) Filed data were collected as follows:

a) The data were collected and accumulated from December 2011 to December 2012. In the beginning, the researcher went to the area with a Cambodian language interpreter for an initial survey of the Rong Kluea Market area. The researcher noticed that there were no child beggars to be seen like there used to be five years ago. The researcher, thus, wondered where and how they had all gone. When the researcher went inside the market, he saw small children carry big bags searching for pieces of paper and plastic from trash cans and piles of garbage that were everywhere in the market. In the back part of the market, is an insect market where all types of insect were sold and bought. Primary-school-age to high-school-age child workers were busy picking insect wings. Some child workers were busy cutting open frogs skillfully. The researcher talked to them and found that most of them knew the interpreter which made it easy for the researcher to talk to them, and to interview foreign child workers who had other occupations.

b) Non-participatory observations were also performed through spending time in the Rong Kluea Market area.

c) In-depth interviews with individual key informants were done only to serve the objectives as the researcher could not speak Cambodian. Hence, the researcher asked the interpreter to interview the Cambodian child workers and the interviews were conducted informally so that the foreign child workers trust the interpreter when they had conversations.

\subsection{Data Analysis}

Content analysis and descriptive analysis were used in qualitative analysis. Content analysis was carried out according to the theories that are used for testing data. Because the group of key informants was a specific group, each key informant was interviewed three times to obtain all the information needed. The data were tested by reading the field notes taken from the interviews to the informants in order to have an opportunity to check the data directly with the data source and some important direct quotes can be placed in the study results (Maxwell, 1992).

The data were processed and analyzed during data collection and after field data were collected. Triangulation was used to test validity and reliability of the data. The data obtained from the same informant were checked using the same interview guidelines but at different times (Patton, 1990). The data were analyzed by classifying and grouping them, and synthesizing relationship patterns to arrive at a conclusion (McMillan \& Schumacher, 1997).

\section{Results}

The results of the study are presented in two issues. The first issue is factors that influenced migration of Cambodian child workers, and the second issue is occupations taken by the migrant Cambodian child workers in the Rong Kluea Market area.

In general, the external characteristics of the migrant Cambodian child workers were: dressed in dirty clothes, thin and looking like having an underlying disease, wearing short or long unhealthy hair, having dried dirty mucus around the nose, and most of them were shoeless. Most of the migrant Cambodian child workers in the Rong Kluea Market area on the Aranyaprathet-Poipet border were originally from rural areas of Cambodia. Their families moved from their place of origin to a new village of Kbal Spean, in Poipet, Ou Chrov District, Banteay Meanchey Province. Most of them had no education as a result of their moving to different places seeking new sources for their occupations, and they usually went to prosperous places with economic development where they could increase and create their income, especially a new area in Poipet next to the Thai border of Aranyaprathet District making it an area for families of foreign child workers. The area had become a slum where workers pays 400-500 baht monthly rent or 1,000 baht for a better condition place to live in.

\subsection{Factors Influencing Migration of Cambodian Child Workers}

\subsubsection{Internal Factors From the Country of Origin}

There were many internal factors from the country of origin that caused foreign child workers to migrate from their place origin. This migration was migration within the country and across the border. The factors could be divided into four groups as follows: 
1) Poverty and family economic status. Most of the foreign child workers and their families were poor farmers from drought areas that were not suitable for investment in growing crops or rice due to the fact the crops they harvested were not enough to raise their families. Some of them did not have their own land to farm on; their parents had no occupation, and had many children.

2) Household debt. Poverty made it necessary for the child workers' families to borrow money to invest in their farming but unfortunately the amount of crops was less than what they needed. Some borrowed money to pay for their trip to work in Thailand. Some borrowed money to invest in their trading but lost; as a result family members had to shoulder the debts and tried to earn more for their families. Some families had debts from gambling and had to sell their land and houses, and had to migrate in order to find money to pay off their debts.

3) Lack of education. Most of the foreign child workers had no education because their families did not have enough money to pay for tuition fees, and they also had many children, and thus, could not send them to school. The children themselves did not want to go to school because they wanted to earn money for their families and their own living. They attached more importance to earning money than going to school.

4) Family conditions. Most of the findings indicated that some of the children were from broken home, their parents were divorced, separated or deceased and the children had to live with their step-parents or their single mothers. Some had to live with new families with new fathers or mothers and then had to migrate with the new families while others had to move to live with relatives or non-government organizations in Poipet.

\subsubsection{The Migration Process of Cambodian Migrant Child Workers}

1) Migration within the country of origin. Migrations of the foreign child workers and their families were migrations from their place of origin to sources with economic development in order to seek higher incomes. They migrated because their relatives, neighbors, or other people migrated. The foreign child workers migrated to a new place with their families and the migration was a result of their parents' or guardians' decision. They migrated because of poverty. The study revealed that Cambodian child workers aged 0-5 years migrated from the rural area to the urban area with their families and they lived in Poipet for 3-10 years or more. Some children were born and grew up in Poipet where their families had come to work and earned enough money to buy a piece of land to build their own house while other families rented a house in Poipet. The rented houses with black rubber sheets, bought from Rong Kluea Market, as walls and roofs to shelter them from the sun and the rain. These houses were surrounded with garbage and full of flies.

2) The migration process of the foreign child workers. Before the foreign child workers made the decision to migrate, in their village or community there had been migrations of their relatives, people they know, or their neighbors. Before they made the decision to migrate, they had seen and heard about better life of the people who had migrated. They also heard of higher incomes made by the migrants which motivated them move to an employment source with economic prosperity that is the trade area situated on the Thai-Cambodian border, especially, the Rong Kluea Market area. Free-trade channels along the border were open which made it easy for foreign child workers to cross the border, some legally and others illegally to work in Thailand, especially children who crossed the border with their parents who came via a shortcut through the forest or small canals along the borderline. The foreign child workers crossed the border on foot to work in the Rong Kluea Market area everyday; they came in the morning and went back in the evening. The trip was convenient with a guide taking them through a shortcut if they wanted a faster trip, and this convenience was known very well among the child workers. On the way, they often faced with border police and they had to pay 10 baht to the police on both sides of borderline. Sometimes they did not have to pay depending on the order or preference of the border police who had power because they were appointed by the states. The children had to obey the order, and in this case the children were oppressed and violated physically; their rights were violated and they had no right to negotiate because of their being other nationality. In addition, negotiations might lead to a loss of the thing of their desire in the country of destination that is the income they expected to earn in the Rong Kluea Market area, their life-sustaining source. Thus, they had to succumb to the situation and face with a safety risk in the Rong Kluea Market area.

3) External factors from the country of destination in the Rong Kluea Market area, a Thai-Cambodian trade area. Incentives from the country of destination are important attractions to the decision-making of the families and children to migrate to another place in order to improve their quality of life. For child workers from poor families, migration to a far away place or another country to work, a lot of money was needed for travel and passport applications. Some families had many children to be responsible for; they could only migrate within their country from their province of origin to another province with prosperity such as the capital city, a prosperous town, important tourist attractions, and the border town with ports of entry. The border town of 
Poipet in Banteay Meanchey Province which is connected to the Thai border at Aranyaprathet District in Sa Kaeo Province, a place of free trade is a source where migrant Cambodian child workers live and work for expected higher incomes.

\subsection{Occupations Taken by Migrant Cambodian Child Workers in the Rong Kluea Market Area}

Rong Kluea Market was a major place where Cambodian children worked in Thailand. The ten categories of work taken by the children were: 1) holding umbrellas to provide shade for tourists, 2) collecting garbage items for sale, 3) taking people across the border through a shortcut, 4) cleaning frogs, 5) cutting off grasshoppers' wings, 6) scraping fish flesh and scaling fishes, 7) pushing goods carts, 8) peddling goods and fruit, 9) shop assistants, and 10) selling sex services.

\section{Holding Umbrellas to Provide Shade for Tourists}

The study found that holding umbrellas to provide shade for tourists was a job taken by both male and female children as it was not too heavy even though they had to be patient waiting for people passing by to use their service. Colorful umbrellas could be bought in Rong Kluea Market for 80 baht each. They hold the umbrellas to provide shade for tourists passing by the border entry point between Rong Kluea Market and Poipet. The service of holding their umbrellas to provide shade was not often called for by tourists. Very often, the child workers did not receive any money for it. However, if they were lucky, they might receive a good amount of money from kind tourists.

\section{Collecting Garbage Items for Sale}

For this job, most of the Cambodian child workers had a large plastic or woven bag that was larger than the children themselves for keeping the garbage items they had collected in. They collected paper, cardboard, plastic, plastic bottles, glass bottles, metal, zinc, soft drink cans, and beer cans. When they had collected enough, they sold them to recycling materials dealers. There were five dealers in the Rong Kluea Market area, two were Cambodians and three were Thai. Mostly the children sold their collected items to dealers who bought at a higher price. The prices on each day were not the same; they went up and down. The garbage items that had been collected could be taken by other workers called garbage robbers. There was a gang of robbers called Bongthom that controlled the garbage collecting areas. The children had to collect garbage items in their own area and not to go over others' areas.

\section{Taking People across the Border through a Shortcut}

Guiding people through a shortcut across the border was a job that the Cambodian child workers did for Thais as well as Cambodians who wanted to cross the border without having to go through the immigration process. The children received 50 baht, and they had to pay the Big Brothers (the rangers on both sides of the border), 70 baht for Thai rangers and 70 baht for Cambodian rangers. They took into account the distance of the route and how much risk there was for them to be arrested. The income they made per day was 300-500 baht. However, there were also days when they earned no money at all. Part of the money they earned was given to their parents or guardians and they kept part of it for themselves.

\section{Cleaning Frogs (Cutting Open Frogs and Removing the Internal Organs)}

Cleaning frogs was a job that child workers had to be employed by an employer. It required a skill in doing this job. The children had to practice using a pointed knife that was used to cut open the frog's abdomen and removing the internal organs. After that they put the frogs into bags and weighed them for sale. Vendors from various provinces came to buy them. Most of the frogs were sent to the northeast of Thailand where there was a high demand for consumption. Cleaning frogs also required a lot of workers, and most of the frog cleaners were Cambodian child workers because the wage was low.

\section{Cutting off Grasshoppers' Wings}

Most of the children who cut off grasshoppers' wings were poor and did not go to school. They knew about the job from their neighbors who said that working in Rong Kluea Market was not difficult and the wage was high. Therefore, they came to do the job. Some children came with their parents who were hired to scrape fish flesh in the fish market. They walked to the Thai market through a small canal that had no water in it. Most of the children came at 5.00 a.m. to cut off grasshoppers' wings while the grasshoppers were still alive. Both wings were cut off to be ready to be fried. This job was done in the rainy season when the grasshoppers were abundant. The children stopped working at 5.00 p.m. and went back home in Cambodia. They bought lunch and ate it in Rong Kluea Market. 


\section{Scraping Fish Flesh and Scaling Fishes}

Children were hired to do this job by employers in the fish market. Each day, there were a lot of child workers who came to keep themselves busy working and competing with time. The environment of the workplace was seen with many kinds of fish piled up on the floor with a lot of flies swarming around. The smell of fresh fish and rotten fish was in the air of the area which was a source of diseases for these child workers.

\section{Pushing Goods Carts}

This job was taken by male Cambodian child workers aged 14-16 years. They bought their trolleys from the Thai market at 750 baht each. Most of them earned 100-300 baht a day depending on the amount of goods that they were hired to carry and push. Most of the child workers had no education because they did not have money to go to school and they wanted to work more than going to school. They walked to work and some of them used to walk through a shortcut and paid 10 baht to a soldier. However, at present they came through the regular route using a border pass and paid 10 baht for it. They came in to the Thai market at $7.30 \mathrm{a} . \mathrm{m}$. and worked until 8.00 p.m.

\section{Peddling of Goods and Fruit}

This job was taken by boys and girls aged 8-15 years. They invested in buying different kinds of fruit and put them in bags and placed them on a small tray that they could peddle. Some of them went around selling items like purses, belts, perfume, and lighters. Some child workers came in illegally until they were old enough to apply for a border pass which cost 220 baht and valid for six months otherwise they could pay 10 baht fee every day. They walked to the market to sell their goods from 8.00 a.m. and went home in Cambodia at around 5.00-6.00 p.m., and came in again the next day.

\section{Shop Assistants}

This job was taken mostly by girls aged 10-16 years old. They were hired to help sell goods in shops situated everywhere in Rong Kluea Market; they sold watches, eye-glasses, handbags, belts, umbrellas, etc. Some of the child workers came in and went back every day while others stayed with their employers, some of them were Thais and others were Cambodians. Their employer rented a room at around 1,500-2,000 baht a month for them to stay in. They worked every day with no days off, and the wage was 100 baht a day. Some of these children said that they did this job because they did not have to work in the sun; all they had to do was speaking nicely to customers. Their employers provided meals for them in addition to a rented room. However, this was up to the employers so they did not have much freedom.

\section{Selling Sex Services}

This job was taken by girls aged 14-18 years, most of whom were Vietnamese-Cambodians. There were about 10 of them in the Rong Kluea Market area. They stood at busy intersections where there were vehicles coming in and going out all the time waiting to catch their guests. They provided two types of services: night services and day services. During the night, they did not entertain guests from faraway places because there had been incidents where children were severely beaten up. During the day time, they wore makeup and dressed in modern styles for the purpose of inviting their guests. In that area, there were also people who tried to invite guests for the girls to get commissions. The guests paid for the rooms while the children either bought protection accessories or received them for free from local organizations. The children admitted that they used drugs like amphetamine and heroin. Some had done the services at Karaoke shops in Koh Kong, Cambodia. If they could not sell their services any more at a place, they just kept moving to another place. Some of them had HIV/Aids and could no longer sell the services or were fired from work. Then they moved to the Thai side to sell their services. The prettiest girls sold their services at 500-700 baht, followed by the less pretty ones at 200-300 baht.

\section{Discussion and Conclusions}

The results of the study on life of Cambodian migrant child workers in the Rong Kluea Market area in Thailand revealed the following:

A. There were three main groups of factors of migration for Cambodian child workers as follows:

1) Internal factors from the country of origin which were poverty and economic status of the family, family conditions, household debts, and children's lack of education,

2) The migration process of the Cambodian child workers was the migration from their country of origin to the country of destination that was from Cambodia to Thailand using the temporary border pass, and crossing the border illegally. Some children came with their parents, guardians, relatives, and acquaintances while others came by themselves. 
3) Factors from the country of destination which was the Rong Kluea Market area, the Thai-Cambodian border trade area that was the economic source with sources of employment, and expected higher incomes than the country of origin. The foreign child workers of Cambodian nationality in the Rong Kluea Market area had many types of jobs to do and to choose from. The work environments varied depending on the characteristics of the jobs. If they were not happy with one job, they could change to another job with higher wages. The working time was from the early morning to late afternoon, and most of the child workers came to work from their home in Cambodia and went back in the late afternoon of each day during the office hours of the immigration. However, some children went back home after the office hours through the shortcut.

\section{B. The occupations of the migrant Cambodian child workers in the Rong Kluea Market area.}

The way of life of the migrant Cambodian child workers in the Rong Kluea Market area in Thailand was that most of them crossed the border legally while some crossed the border illegally to work in Thailand. There were 10 major types of occupations: 1) holding umbrellas to provide shade for tourists, 2) collecting garbage items for sale, 3) taking people across the border through a shortcut, 4) cleaning frogs, 5) cutting off grasshoppers' wings, 6) scraping fish flesh and scaling fishes, 7) pushing goods carts, 8) peddling goods and fruit, 9) shop assistants, and 10) selling sex services.

Factors of the migration of Cambodian children to work in the Rong Kluea Market area in Thailand were related to their family background in terms of poverty, lack of education, and incentives available in the Rong Kluea Market area which was a source of employments where the children could choose the kinds of job they liked to do whether to work independently or dependently with employers. Some children fall victims to human-trafficking and are forced to work in large cities of Thailand such as Phattaya, Bangkok, Phuket, Hat Yai, etc. Sasanasuphin, Ayuwat and Tongyu, (2011) found that migrants who fall victims to human trafficking were mostly children and youths with no education and with low income. These children are workers who usually are not protected in terms of human rights and their rights are violated by employers. Sometimes migration can lead people to being stateless; this is in accordance with a study by Lee (2005) who found that transnational workers is a process that can lead migrants to being stateless and do not have protection according to human rights principles.

Nevertheless, Cambodian child workers in the Rong Kluea Market area who take various kinds of job were found to take jobs that were suitable for their age and skills. However, there is a concern since these child workers have development and they see some types of work model of children who are older, especially selling sexual services that Cambodian girls aged 16-18 years do. They see that it is not a tiring job and it is an easy-money job. Therefore, when child workers grow up, more children change their job, for example, from holding umbrellas to provide shade for tourists, peddling goods and fruit, or working as shop assistants, etc. to selling sex services. These children also use drugs, smoke, and some have HIV, some escape to tourist towns or large cities of Thailand to sell sex services. Sometimes they fall victims to human-trafficking that has become a social problem that the Thai government should attach importance to. In addition, the Thai government should also control and provide more care for these transnational child workers. The government must give importance to, and form policy for solving the problem according to human rights principles.

The policy recommendations as follows:

1) The Thai and the Cambodian governments should give more importance to cross-border child workers by forming policy to promote and improve quality of life of child workers in terms of education, health, and quality of life in general so that they are protected as human beings and not becoming stateless people in the future.

2) There should be flexibility for border crossing. However, there should also be clear registration of these child workers so that agencies or organizations related to human rights can concretely provide support and take care of quality of life of cross-border child workers.

3) Cross-national child workers should be treated taking into consideration human rights principles and equality as human beings; at present, they have become marginal people with no rights and some of them are stateless.

4) The Thai government should form policy related, particularly, to transnational child workers which could be in the form of law or bills that are different from other types of labor taking into consideration their being children and youths requiring leniency, and to be protected as child workers. 


\section{References}

Castles, S. (2005). Hierarchical citizenship in a world of unequal nation-states. Political Science and Politics, 38(4), 689-692.

Castles, S., \& Miller, M. (1993). The age of migration: International population movements in the modern world. Hampshire and London: Macmillan Press.

Donnan, H., \& Wilson, T. M. (1999). Border: Frontiers of identity, nation and state. Oxford: Berg.

International Labor Organization. (2004). Towards a fair deal for migrant workers in the global economy. Retrieved February 20, 2012, from http://www.ilo.org/global/Themes/Labour_migration/lang--en docName--KD0096/index.htm

International Organization for Migration (2008). World Migration Report 2008. Retrieved February 20, 2012, from http://www.iom.int/jahia/Jahia/cache/offonce/pid/1674? entryId=20275

Lee, T. L. (2005). Statelessness, human rights and gender: Irregular migrant workers from Burma in Thailand. Leiden/Boston: Martinus Nijholf Publisher.

Maxwell, J. A. (1992). Understanding reliability and validity in qualitative research. Harvard Educational Review, 62(3), 279-300.

McMillan, J. H., \& Schumacher, S. (1997). Research in education: A conceptual introduction (4th ed.). New York: Longman.

Patton, M. Q. (1990). Qualitative evaluation and research methods (2nd ed.). Newbury Park, CA: Sage.

Pearson, E., Punpuing, S., Jampaklay, A., Kittisuksathit, S., \& Prohmmo, A. (2006). The Mekong challenge: Underpaid, overworked and overlooked: The realities of young migrant workers in Thailand. Bangkok: International Labor Organization.

Sasanasuphin, P., Ayuwat, D., \& Tongyu, M. (2011). Transnational migration processes of victims-migrant trafficking. KKU Research Journal, 1(1), 95-110.

Sciortino, R., \& Punpuing, S. (2009). International migration in Thailand, 2009. Bangkok: International Organization for Migration.

\section{Copyrights}

Copyright for this article is retained by the author(s), with first publication rights granted to the journal.

This is an open-access article distributed under the terms and conditions of the Creative Commons Attribution license (http://creativecommons.org/licenses/by/3.0/). 